Picturing the Uncertain World 



\title{
Picturing the Uncertain World
}

\author{
How to Understand, Communicate, \\ and Control Uncertainty through \\ Graphical Display
}

\section{Howard Wainer}

Princeton University Press

Princeton E Oxford 
Copyright (C) 2009 by Princeton University Press

Published by Princeton University Press, 41 William Street, Princeton, New Jersey 08540

In the United Kingdom: Princeton University Press, 6 Oxford Street, Woodstock, Oxfordshire OX20 1TW

All Rights Reserved

Library of Congress Cataloging-in-Publication Data

Wainer, Howard.

Picturing the uncertain world : how to understand, communicate, and control uncertainty through graphical display / Howard Wainer.

p. $\mathrm{cm}$.

Includes bibliographical references and index. ISBN 978-0-691-13759-9 (cloth : alk. paper)

1. Uncertainty (Information theory)-Graphic methods. 2. Communication in science-Graphic methods. I. Title. Q375.W35 2009

$003^{\prime} .54-\mathrm{dc} 22$

British Library Cataloging-in-Publication Data is available

This book has been composed in Adobe Jenson Pro and DIN Pro

Printed on acid-free paper. $\infty$

press.princeton.edu

Printed in the United States of America

13579108642 
To my colleagues, past and present, who contributed their ideas and their kind thoughts.

This book is the result of the beauty of their minds and the labor of mine.

Sine quibus non 
